Tilo Andus ${ }^{\bigcirc}$

Peter C. Heinrich ${ }^{\circ}$,

Joachim Bauer ${ }^{\triangle}$,

Thuy-Anh Tran-Thi ${ }^{\circ}$,

Karl Decker ${ }^{\circ}$

Daniela Männel ${ }^{\square}$ and

Hinnak Northoff ${ }^{+}$

Biochemisches Institut $^{\circ}$, Universität

Freiburg, Freiburg, Medizinische

Universitätsklinik ${ }^{\triangle}$, Freiburg, DKFZ,

Institut für Immunologie und Genetik ${ }^{\square}$,

Heidelberg and Blutspendezentrale des

DRK $^{+}$, Ulm

\section{Discrimination of hepatocyte-stimulating activity from human recombinant tumor necrosis factor $\alpha^{*}$}

\begin{abstract}
The involvement of tumor necrosis factor $\alpha$ (TNF $\alpha)$ in the regulation of acute-phase protein synthesis is currently under discussion.In this study the effect of human recombinant TNF $\alpha$ on the regulation of the 4 acute-phase proteins $\alpha_{2}$-macroglobulin, albumin, $\alpha_{1}$-proteinase inhibitor and $\alpha_{1}$-acute-phase globulin was investigated in rat hepatocyte primary cultures. No changes in synthesis of any of the 4 proteins were observed. However, an acute-phase response similar to that in vivo could be generated by conditioned media from human monocytes containing natural TNFa. This response remained unchanged after neutralizing TNF $\alpha$ activity by the addition of a specific antibody to TNFo. It is concluded that the hepatocyte-stimulating activity synthesized by human monocytes is different from TNFa.
\end{abstract}

\section{Introduction}

Injuries such as bacterial or parasitic infections, physical and chemical traumata, malignant tumors and immunologic disorders lead to a highly complex reaction of the organism, the socalled acute-phase response [1-3]. The acute-phase response is characterized by fever, leukocytosis, a negative nitrogen balance and an increase in the synthesis of hepatic acute-phase proteins (APP) [4,5]. These changes are generated by mediators secreted from mononuclear phagocytes. Many efforts have been made to identify these mediator molecules and to study their functions. Interleukin 1 (II 1) was the first of these mediators which became available in a pure state and in large quantity by molecular cloning [6-11]. More recently, a second monokine, cachectin/tumor necrosis factor $\alpha$ (TNF $\alpha)$, has been cloned and characterized [12-16].

In previous studies we have investigated the biosynthesis and regulation of APP in vivo and in rat hepatocyte primary cultures [17-27]. Conditioned media from rat Kupffer cells $[23,28,29]$ and human monocytes $[23,27,30-34]$ were able to induce APP synthesis in rat hepatocytes. It was therefore of great interest to identify the factor(s) responsible for the induction of APP in hepatocytes. As a first candidate we tested murine recombinant IL 1 for its potency to stimulate the synthesis of $\alpha_{2}$-macroglobulin $\left(\alpha_{2} M\right)$, a strong APP in the rat. Only a weak $\alpha_{2} \mathrm{M}$ induction was observed [26]. Moreover, $\alpha_{2} \mathrm{M}$ synthesis in rat hepatocytes was strongly stimulated by conditioned human monocyte media lacking any IL 1 activity $23,27]$. From these findings it became evident that a factor different from IL 1 is involved in the induction of APP in rat hepatocytes. This is in good agreement with the observations made by other authors $[31,32,35,36]$. Ritchie and Fuller [30] designated the APP-inducing activity distinct from IL 1 as hepatocyte-stimulating factor (HSF).

[I 6036]

\footnotetext{
* This work was supported by grants from the Deutsche Forschungsgemeinschaft, Bonn, and the Fonds der Chemischen Industrie, Frankfurt.
}

Correspondence: Peter C. Heinrich, Biochemisches Institut, Hermann-Herder-Str. 7, D-7800 Freiburg, FRG

Abbreviations: APP: Acute phase protein(s) $\alpha_{1}$ APG: $\alpha_{1}$-Acutephase globulin $\alpha_{1}$ PI: $\alpha_{1}$-Proteinase inhibitor HSF: Hepatocytestimulating factor IL 1: Interleukin 1 LPS: Lipopolysaccharide TCA: Trichloroacetic acid TNFa: Tumor necrosis factor $\alpha$
Recently, acute-phase protein-inducing activity was attributed to cachectin/TNF $\alpha[33,37]$. Since HSF is still poorly characterized, the question arose whether or not HSF is identical with TNF $\alpha$.

In the present communication we show that recombinant human TNF $\alpha$ as well as TNF $\alpha$ produced by human peripheral blood monocytes does not induce changes in the synthesis of $\alpha_{2} \mathrm{M}$, albumin, $\alpha_{1}$-proteinase inhibitor $\left(\alpha_{1} \mathrm{PI}\right)$ and $\alpha_{1}$-acutephase globulin ( $\left.\alpha_{1} A P G\right)$ in rat hepatocyte primary cultures.

\section{Materials and methods}

\subsection{Chemicals}

$L-\left[{ }^{35} \mathrm{~S}\right]$ Methionine $(46 \mathrm{TBq} / \mathrm{mmol})$ was purchased from the Radiochemical Centre, Amersham, GB. Protosol was obtained from New England Nuclear, Boston, MA, and protein A-Sepharose CL-4B from Pharmacia, Freiburg, FRG. RPMI 1640 medium and phenylmethylsulfonyl fluoride were from Serva, Heidelberg, FRG. Fetal calf serum was purchased from Gibco, Eggenstein, FRG. Penicillin and streptomycin were from Seromed, Berlin, FRG. Insulin, actinomycin D and crystal violet were obtained from Sigma, Deisenhofen, FRG. Kallikrein trypsin inhibitor (Trasylo ${ }^{\circledR}$ ) was generously supplied by Bayer AG., Leverkusen, FRG. Lipopolysaccharide derived from Salmonella typhimurium was from Difco, Detroit, MI. Recombinant TNF $\alpha$ was generously supplied by BASF AG., Ludwigshafen, FRG. It contained less than $1.3 \mathrm{ng}$ endotoxin per $\mathrm{mg}$ protein. Rabbit antisera containing polyclonal anti-TNF $\alpha$ antibodies were generated by immunizing rabbits (New Zealand White) with recombinant human TNF $\alpha$. A serum dilution of $1: 2000$ neutralized completely $10 \mathrm{ng} / \mathrm{ml}$ recombinant $\mathrm{TNF} \alpha$ in the TNF $\alpha$ cytotoxicity assay.

\subsection{Preparation of rat hepatocyte monolayers}

Suspensions of rat hepatocytes were prepared as previously described by Tran-Thi et al. [38]. After washing the cells with Krebs-Henseleit buffer they were suspended in a modified Waymouth medium [39] containing $10 \%$ fetal calf serum, $50 \mathrm{U} / \mathrm{ml}$ penicillin, $50 \mu \mathrm{g} / \mathrm{ml}$ streptomycin and $1 \mu \mathrm{M}$ insulin. The high insulin concentration was chosen because insulin has been shown to enhance cell viability [40] and to be required for monolayer formation of hepatocytes [41]. Furthermore, insulin is rapidly degraded by hepatocyte cultures at $37^{\circ} \mathrm{C}$ [42]. 
Aliquots of $0.3 \mathrm{ml}$ cell suspension $\left(2.5 \times 10^{5}\right.$ cells $)$ were added to $16 \mathrm{~mm}$ contour-bottom Falcon plastic tissue culture dishes (Falcon, Oxnard, CA). The dishes were incubated at $37^{\circ} \mathrm{C}$ in a humid atmosphere of air: $\mathrm{CO}_{2}(95 \%: 5 \%)$ for $3 \mathrm{~h}$. The plates were then washed with Krebs-Henseleit buffer and $0.3 \mathrm{ml}$ culture medium was added as described [43]. Confluent monolayers were formed after an overnight incubation at $37^{\circ} \mathrm{C}$ in a humid atmosphere of air: $\mathrm{CO}_{2}(95 \%: 5 \%)$. The hepatocyte primary cultures consisted of more than $97 \%$ hepatocytes. The cultures were routinely controlled by microscopic examination prior to each experiment.

\subsection{Labeling of hepatocytes}

RPMI 1640 medium was used for the radioactive labeling of the hepatocytes. Three hundred $\mathrm{kBq}$ of $\left[{ }^{35} \mathrm{~S}\right]$ methionine was added to $0.3 \mathrm{ml}$ of methionine-free culture medium for the labeling of proteins. After incubation at $37^{\circ} \mathrm{C}$ for $3 \mathrm{~h}$, the media were separated from the cells and centrifuged at $12000 \times \mathrm{g}$ for $5 \mathrm{~min}$ and used for immunoprecipitation.

\subsection{Immunoprecipitation}

The preparation of antisera against rat $\alpha_{2} \mathrm{M}$, albumin, $\alpha_{1} \mathrm{PI}$ and $\alpha_{1}$-acute-phase globulin ( $\alpha_{1}$ APG) has been previously described $[17,19,24]$. Immunoprecipitations were carried out in the presence of an excess of antibody. Hepatocyte medium containing $10^{5} \mathrm{cpm}$ of trichloroacetic acid (TCA)-precipitable radioactivity was added to $1 \mathrm{ml}$ buffer $\mathrm{A}(20 \mathrm{mM}$ Tris $/ \mathrm{HCl}$, pH 7.6, $0.14 \mathrm{M} \mathrm{NaCl}, 5 \mathrm{~mm}$ EDTA, $1 \%$ Triton X-100) containing $1 \mathrm{mM}$ phenylmethylsulfonyl fluoride and $0.1 \mathrm{mg}$ of kallikrein trypsin inhibitor. After addition of $5 \mu 1$ of specific antiserum and incubation at $4{ }^{\circ} \mathrm{C}$ overnight, the antigen-antibody complexes were bound to $7 \mathrm{mg}$ (dry weight) of protein A-Sepharose and washed four times with buffer $\mathrm{A}$ and twice with $50 \mathrm{~mm}$ sodium phosphate buffer, $\mathrm{pH} 7.5$. Elution was achieved by incubation with $0.1 \mathrm{M}$ Tris/ $\mathrm{HCl}, \mathrm{pH} 6.8,5 \%$ 2-mercaptoethanol, $5 \%$ sodium dodecyl sulfate and $10 \%$ glycerol at $95^{\circ} \mathrm{C}$ for $5 \mathrm{~min}$. The eluted proteins were analyzed by sodium dodecyl sulfate-polyacrylamide gel electrophoresis [44] and subjected to fluorography according to Bonner and Laskey [45]. For the quantification of the radioactivity incorporated into the different APP, the corresponding bands identified by fluorography were cut from the gels, solubilized with Protosol/water $(9: 1, \mathrm{v} / \mathrm{v})$ at $45^{\circ} \mathrm{C}$ overnight and counted in a liquid scintillation spectrometer.

\subsection{Preparation of human monocytes and conditioned media}

Human mononuclear leukocytes were prepared from buffy coats of normal blood units by density gradient centrifugation [46]. Four $\times 10^{6}$ human mononuclear leukocytes $/ \mathrm{ml}$ were incubated at $37^{\circ} \mathrm{C}$ in a humid atmosphere containing $5 \% \mathrm{CO}_{2}$ for $2 \mathrm{~h}$ in plastic culture flasks (Falcon 3024F) in RPMI 1640 medium supplemented with $2 \%$ human serum. Nonadherent cells were removed by two washes with the above medium. The adherent cells were then reconstituted with the same medium, incubated for $24 \mathrm{~h}$ in the presence of $1 \mathrm{ng}$ of lipopolysaccharide (LPS) per $\mathrm{ml}$ and the supernatants were harvested by centrifugation and filtration (Nalgene $\mathrm{SCN}$, $45 \mu \mathrm{m}$, Nalge/Sybron, Rochester, NY). Alternatively, adhe- rent cells were pre-incubated for $24 \mathrm{~h}$ in the absence of stimulant and then incubated with LPS for further $24 \mathrm{~h}$.

\subsection{TNF $\alpha$ assay}

The cytotoxicity assay for TNF $\alpha$ was carried out on sensitive L929 mouse fibrosarcoma cells $\left(2 \times 10^{4}\right.$ cells $/ 0.2 \mathrm{ml}$ culture $)$ in the presence of actinomycin D $(2 \mu \mathrm{g} / \mathrm{ml})$ in RPMI 1640 medium containing $10 \%$ heat-inactivated fetal calf serum. The cultures contained serial dilutions of TNFa samples. After $20 \mathrm{~h}$ of culture, the surviving cells were fixed and stained with crystal violet $[0.5 \%$ crystal violet, $8 \%(\mathrm{v} / \mathrm{v})$ formaldehyde (37\%), $0.17 \mathrm{NaCl}, 22.3 \%$ ethanol] for $15 \mathrm{~min}$. Excess dye was washed off with water and the remaining dye solubilized in $33 \%$ acetic acid. Absorbance was measured at $540 \mathrm{~nm}$. Concentrations of TNF $\alpha$ were determined by comparing the dilutions at which $50 \%$ survival was measured with a recombinant TNF $\alpha$ reference, kindly supplied by BASF AG.

\subsection{IL 1 assay}

Supernatants of stimulated human monocytes and controls were assayed for IL 1 in the costimulation assay on $\mathrm{C} 3 \mathrm{H} / \mathrm{HeJ}$ thymocytes as described [47].

\section{Results}

Rat hepatocyte primary cultures were incubated with different amounts of recombinant human $\mathrm{TNF} \alpha$ ranging from $1 \mathrm{pg}$ to $10 \mu \mathrm{g}$ per $\mathrm{ml}$ medium for $12 \mathrm{~h}$ at $37^{\circ} \mathrm{C}$ and proteins were labeled with $\left[{ }^{35} \mathrm{~S}\right]$ methionine. Three positive APP, $\alpha_{2} \mathrm{M}$, $\alpha_{1}$ APG and $\alpha_{1}$ PI, known to show very strong, strong or weak increases during inflammation (reviewed in [3]) and the negative APP albumin were immunoprecipitated from the media of hepatocytes incubated with TNF $\alpha$. Fig. 1 shows that recombinant TNF $\alpha$ did not affect the synthesis of any of the 4 selected rat APP. Since we found murine recombinant IL 1 to be a weak stimulator of $\alpha_{2} \mathrm{M}$ synthesis in rat hepatocytes [26], we studied the combined action of IL 1 and TNF $\alpha$, in order to test whether TNF $\alpha$ enhances IL 1 activity. No synergistic effect of TNF $\alpha$ and IL 1 was observed (data not shown). Since recombinant TNF $\alpha$ may have properties different from the physiologically synthesized material, conditioned media from LPS-stimulated human monocytes containing TNF $\alpha$ were added to hepatocyte primary cultures. A concentration of $0.5 \mathrm{ng} \mathrm{TNF} \alpha / \mathrm{ml}$ was determined in the monocyte media.

As shown in Fig. 2A, last column, conditioned monocyte media stimulated $\alpha_{2} \mathrm{M}$ synthesis 25 -fold and $\alpha_{1} \mathrm{APG}$ synthesis 2.5-fold, whereas $\alpha_{1}$ PI did not change. Albumin synthesis was decreased by $60 \%$. These changes in the syntesis of the four APP are quite similar to those observed in vivo during inflammation. Thus, the conditioned medium of human monocytes contains inflammatory mediators leading to the induction of APP synthesis. Addition of a neutralizing antibody to TNF $\alpha$ should abolish the acute-phase response, if TNF $\alpha$ present in the monocyte medium is indeed the inducer of APP synthesis in hepatocytes. We therefore pre-incubated the conditioned media with diffeent amounts of anti-TNF $\alpha$ prior to the addition to hepatocytes. As shown in Fig. 2A, B, first 3 columns, no inhibition of the acute-phase induction was observed, 

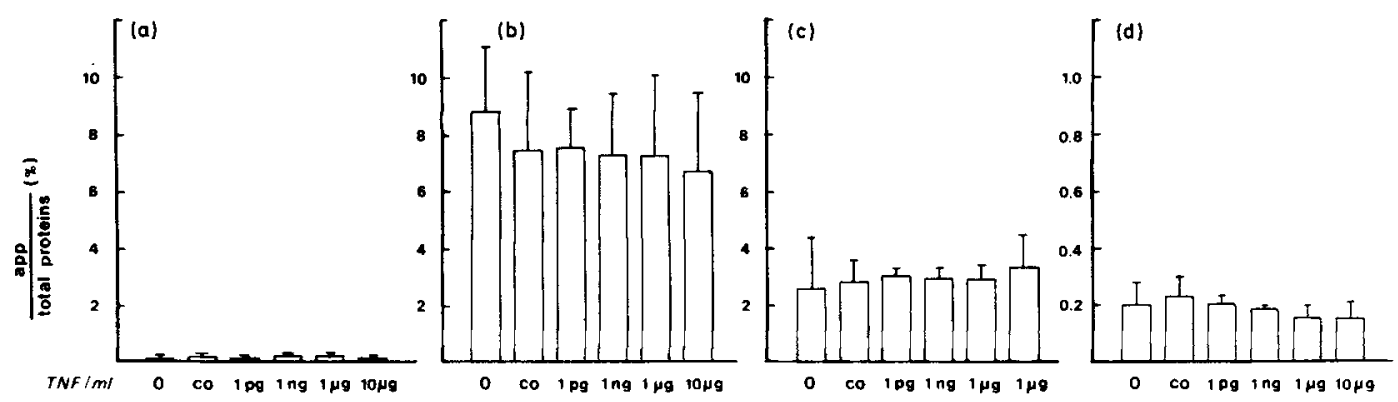

[50036.0]

Figure 1. Effect of human recombinant TNF $\alpha$ on the synthesis of APP in rat hepatocyte primary cultures. Rat hepatocyte primary cultures were prepared as described in Sect. 2.2 and kept in culture for 5 days. As indicated in the figure, TNF $\alpha$ in different concentrations was added to the hepatocytes. The specific activity of the TNF $\alpha$ preparation was $2 \times 10^{7}$ units $/ \mathrm{mg}$. As a control (Co) the medium (RPMI $1640,1 \%$ fetal calf serum) in which TNF $\alpha$ had been diluted was added to the hepatocytes. After incubation for $12 \mathrm{~h}$, cells were labeled with [ $\left.{ }^{35} \mathrm{~S}\right] \mathrm{methionine}$ for $3 \mathrm{~h}$. $\alpha_{2} \mathrm{M}$ (a), albumin (b), $\alpha_{1}$ PI (c) and $\alpha_{1}$ APG (d) were immunoprecipitated from the hepatocyte media containing $10^{5} \mathrm{cpm}$ of TCA-precipitable radioactivity and subjected to sodium dodecyl sulfate-polyacrylamide gel electrophoresis and fluorography. The radioactivity of the immunoprecipitated proteins was related to the total TCA-precipitable material. Data are means \pm SD of 3 different experiments.

Table 1. TNF $\alpha$ activity neutralized by anti-TNF $\alpha$

\section{Dilution of anti-TNF $\alpha$}

TNF $\alpha$ activity (titer) $)^{\text {a) }}$

$\begin{array}{lr}1: 1000 & <2 \\ 1: 100 & <2 \\ 1: 10 & <2 \\ \text { No addition } & 16 \\ \text { Control antiserum } & 16\end{array}$

a) Titers of TNF $\alpha$ activity are given as the reciprocal dilutions at which $50 \%$ survival was measured in the TNF $\alpha$ assay. although the antibody had neutralized TNF $\alpha$ activity completely (Table 1).

Since the conditioned medium from LPS-stimulated freshly prepared human monocytes contains IL 1 activity, we examined whether IL 1 might be responsible for the acute phase induction. It is known that human monocytes lose their capability to secrete IL 1 after pre-incubation for $24 \mathrm{~h}$ prior to LPS stimulation [48-50]. When conditioned media from preincubated and stimulated human monocytes were added to hepatocytes, the acute-phase induction was still observed, although slightly diminished (Fig. 2B). Addition of different amounts of anti-TNF $\alpha$ to the pre-incubated conditioned media also did not affect the APP-inducing capacity.
(A)
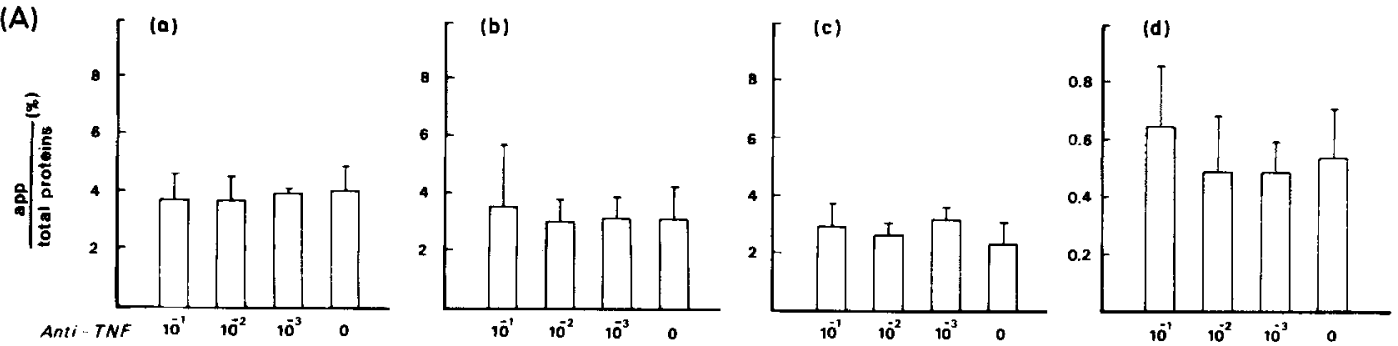

(B)
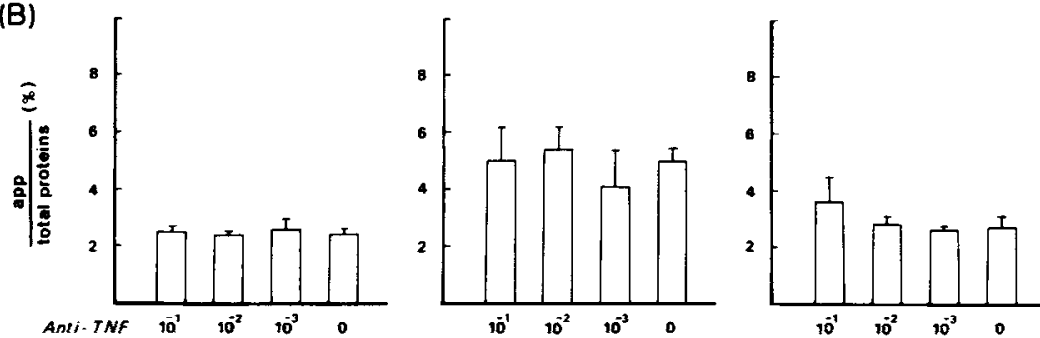

16036.2

Figure 2. Effect of anti-TNF $\alpha$ on the synthesis of acute-phase proteins induced by conditioned media from human monocytes. Conditioned media from LPS-stimulated human monocytes $0-24 \mathrm{~h} \mathrm{(A)} \mathrm{or} \mathrm{24-48} \mathrm{h} \mathrm{(B)} \mathrm{after} \mathrm{preparation} \mathrm{from} \mathrm{human} \mathrm{blood} \mathrm{were} \mathrm{incubated} \mathrm{for} 30$ min at room temperature with different amounts of a monospecific antibody to human recombinant TNF $\alpha$ at the final concentrations indicated. The antibody-treated conditioned media were added to hepatocyte primary cultures. After incubation for $12 \mathrm{~h}$, hepatocytes were labeled with $\left[{ }^{35}\right.$ S]methionine and the synthesis of $\alpha_{2} \mathrm{M}$ (a), albumin (b), $\alpha_{1} \mathrm{PI}$ (c) and $\alpha_{1} \mathrm{APG}$ (d) was measured described in Sect. 2.4. The conditioned medium from freshly prepared monocytes (A) contained IL 1 (titer 64) in the thymocyte assay, while conditioned medium from pre-incubated monocytes (B) contained no detectable IL 1 at all. 
We conclude from these results that TNFa is not the main mediator of the acute-phase response in rat hepatocyte primary cultures. Furthermore, it is evident that a mediator different from IL 1 is present in conditioned media from freshly prepared as well as from pre-incubated human monocytes after LPS induction.

\section{Discussion}

At first sight, our finding that human recombinant TNF $\alpha$ is not involved in the induction of seveal APP in rat hepatocytes is in contrast to the observations of Perlmutter et al. [37] and Darlington et al. [33]. These authors described stimulation of complement factor $\mathrm{C} 3$, factor $\mathrm{B}$ and $\alpha_{1}$-antichymotrypsin in HepG2 and Hep3B2 cells by human recombinant TNFa. However, several other APP such as complement factors C2 and $\mathrm{C} 4, \alpha_{1} \mathrm{PI}$, fibrinogen, $\alpha_{1}$-acid glycoprotein, C-reactive protein and haptoglobin did not respond to TNF $\alpha$. For the negative APP albumin Perlmutter et al. [37] observed a decrease in synthesis, whereas Darlington et al. [33] did not detect a change after addition of human recombinant TNF $\alpha$ to human hepatoma cells. Taken together, TNF $\alpha$ was found to induce only a very limited number of APP.

Both groups used tumor cell lines for their experiments. Therefore, their data should be interpreted with reservation. Tumor cells, as dedifferentiated cells, may not be the ideal model system to study the regulation of APP synthesis. In our study we avoided the use of a tumor cell line. Since human hepatocyte primary cultures are hardly available, we have used rat hepatocyte primary cultures. In response to conditioned medium from human monocytes rat hepatocytes synthesize APP similarly to the rat liver in vivo during inflammation. Thus, it is unlikely that species specificity is responsible for the lacking effect of human recombinant TNFo on rat hepatocytes. This view is supported by experiments of Tracey et al. [51] who found that human recombinant TNFa exerts a strong action in the rat. Recently, Smith et al. [52] described human and mouse TNF $\alpha$ to be active in heterologous cell systems, although the concentrations of $\mathrm{TNF} \alpha$ needed were higher than in the homologous system.

From the fact that human recombinant $\mathrm{TNF} \alpha$ did not induce $\alpha_{2} \mathrm{M}, \alpha_{1}$ APG or $\alpha_{1}$ PI synthesis in rat hepatocytes, while conditioned medium from human monocytes was a potent stimulator, it must be concluded that TNF $\alpha$ is distinct from HSF.

IL 1 was reported to induce several APP in rat hepatocyte primary cultures. Previously we described a 2-fold stimulation of $\alpha_{2} \mathrm{M}$ synthesis by murine recombinant IL 1 [26]. Ramadori et al. [53] described the induction of serum amyloid $\mathrm{A}$ and factor B by murine recombinant IL 1 in vivo and in hepatocyte primary cultures from mice. Increases in the synthesis of $\alpha_{1}$ antichymotrypsin, factor $\mathrm{B}$ and $\mathrm{C} 3$, but not $\mathrm{C} 2, \mathrm{C} 4$ and $\alpha_{1} \mathrm{PI}$ were observed in Hep3B cells upon addition of human recombinant IL 1 [37]. Using HepG2 cells, Karin et al. [54] induced metallothioneine mRNA by recombinant murine IL 1 . As in the case of TNF $\alpha$, Darlington et al. [33] reported that among several APP tested in Hep3B2 cells mouse recombinant IL 1 induced only the synthesis of $\mathrm{C} 3$. In rat hepatocytes Fuller et al. [31] did not observe any stimulation of fibrinogen synthesis by murine recombinant IL 1 .
From the fact that some APP are inducible by IL 1, whereas others are not, it is evident that IL 1 is not an universal mediator in APP induction.

In this study we have presented data which shows that TNF $\alpha$ did not induce rat $\alpha_{2} \mathrm{M}$ synthesis, whereas conditioned media of human monocytes devoid of TNF $\alpha$ and IL 1 activities were still capable of stimulating $\alpha_{2} \mathrm{M}$ synthesis 10 -fold. Thus, a factor distinct from TNF $\alpha$ and of much higher potency than IL 1 is involved in the induction of APP.

We are grateful to $H$. Wintersinger and $K$. Gyufko for their technical assistance and to $H$. Gottschalk for her help with the preparation of the manuscript.

Received March 2, 1987; in revised form May 20, 1987.

\section{References}

1 Kushner, I., Ann. N. Y. Acad. Sci. 1982. 389: 39.

2 Schreiber, G. and Howlett, G., in Glaumann, H., Peters, T. and Redman, C. (Eds.), Plasma Protein Secretion by the Liver, Academic Press, London 1983, p. 423.

$3 \mathrm{Koj}$, A., in Koj, A. and Gordon, A. H. (Eds.), The Acute Phase Response to Injury and Infection, Elsevier, Amsterdam 1985, p. 23.

4 Dinarello, C. A., N. Engl. J. Med. 1984. 311: 1413.

5 Sipe, J. D., in Koj, A. and Gordon, A. H. (Eds.), The Acute Phase Response to Injury and Infection, Elsevier, Amsterdam 1985, p. 23.

6 Lomedico, P. T., Gubler, U., Hellmann, C. P., Dukovich, M., Giri, J. G., Pan, Y-C. E., Collier, K., Semionow, R., Chua, A. O. and Mizel, S. B., Nature 1984. 312: 458.

7 Auron, P. E., Webb, A. C., Rosenwasser, L. J., Mucci, S. F. Rich, A., Wolff, S. M. and Dinarello, C. A., Proc. Natl. Acad. Sci. USA 1984. 81: 7907.

8 March, C. J., Mosley, B., Larsen, A., Cerretti, D. P., Braedt, G., Price, V., Gillis, S., Henney, C. S., Kronheim, S. R., Grabstein, K., Conlon, P. J., Hopp, T. P. and Cosman, D., Nature 1985. 315: 641.

9 Furutani, Y., Notake, M., Yamayoshi, M., Yamagishi, J., Nomura, H., Ohue, M., Furuta, R., Fukui, T.,Yamada, M. and Nakamura, S., Nucleic Acids Res. 1985. 13: 5869.

10 Wingfield, P., Payton, M., Tavernier, J., Barnes, M., Shaw, A., Rose, K., Simona, M. G., Demczuk, S., Williamson, K. and Dayer, J.-M., Eur. J. Biochem. 1986. 160: 491.

11 Noma, T., Nakamura, T., Maeda, M., Okada, M., Taniguchi, Y., Tagaya, Y., Yaoita, Y., Yodoi, J. and Honjo, T., Biochem. Biophys. Res. Commun. 1986. 139: 353.

12 Pennica, D., Nedwin, G. E., Hayflick, J. S., Seeburg, P. H., Derynck, R., Palladino, M. A., Kohr, W. J., Aggarwal, B. B. and Goeddel, D. V., Nature 1984. 312: 724.

13 Wang, A. M., Creasey, A. A., Ladner, M. B., Lin, L. S., Strickler, J., Van Arsdell, J. N., Yamamoto, R. and Mark, D. F., Science 1985. 228: 149.

14 Fransen, L., Muller, R., Marmenout, A., Tavernier, J., Van der Heyden, J., Kawashima, E., Chollet, A., Tizard, R., Van Heuverswyn, H., Van Vliet, A., Ruysschaert, M.-R., and Fiers, W., Nucleic Acids Res. 1985. 13: 4417.

15 Caput, D., Beutler, B., Hartog, K., Thayer, R., Brown-Shimer, S. and Cerami, A., Proc. Natl. Acad. Sci. USA 1986. 83: 1670.

16 Ito, H., Yamamoto, S., Kuroda, S., Sakamoto, H., Kajihara, J., Kiyota, T., Hayashi, H., Kato, M. and Seko, M., DNA 1986. 5: 149.

17 Geiger, T., Northemann, W., Schmelzer, E., Gross, V., Gauthier, F. and Heinrich, P,. C., Eur. J. Biochem. 1982. 126: 189.

18 Gross, V., Geiger, T., Tran-Thi, T.-A., Gauthier, F. and Heinrich, P. C., Eur. J. Biochem. 1982. I29: 317. 
19 Andus, T., Gross, V., Tran-Thi, T.-A., Schreiber, G., Nagashima, M. and Heinrich, P. C., Eur. J. Biochem. 1983. 133: 561.

20 Northemann, W., Andus, T., Gross, V., Nagashima, M., Schreiber, G.and Heinrich, P. C., FEBS Lett. 1983. 161: 319.

21 Northemann, W., Andus, T., Gross, V. and Heinrich, P. C., Eur. J. Biochem. 1983. 137: 257.

22 Gross, V., Andus, T., Tran-Thi, T.-A., Bauer, J., Decker, K. and Heinrich, P. C., Exp. Cell Res. 1984. 151: 46.

23 Bauer, J., Birmelin, M., Northoff, G.-H., Northemann, W., TranThi, T.-A., Ueberberg, H., Decker, K. and Heinrich, P. C., FEBS Lett. 1984. 177: 89.

24 Bauer, J., Kurdowska, A., Tran-Thi, T.-A., Budek, W., Koj, A., Decker, K. and Heinrich, P. C., Eur. J. Biochem. 1985. 146: 347.

25 Northemann, W., Heisig, M., Kunz, D. and Heinrich, P. C., J. Biol. Chem. 1985. 260: 6200 .

26 Bauer, J., Weber, W., Tran-Thi, T.-A., Northoff, G.-H., Decker, K., Gerok, W. and Heinrich, P. C., FEBS Lett. 1985. 190: 271.

27 Bauer, J., Tran-Thi, T.-A., Northoff, H., Hirsch, F., Schlayer, H.J., Gerok, W. and Heinrich, P. C., Eur. J. Cell Biol. 1986. 40: 86.

28 Hirata, Y., Ishibashi, H., Kimura, H., Hayashide, K., Nagano, M. and Okubo, H., Inflammation 1985. 9: 201.

29 Sanders, K. D. and Fuller, G. M., Thrombosis Res. 1983. 32: 133.

30 Ritchie, D. G. and Fuller, G. M., Ann. N. Y. Acad. Sci. 1983. 408: 490.

31 Fuller, G. M., Otto, J. M., Woloski, B. M., McGary, C. T. and Adams, M. A., J. Cell Biol. 1985. 101: 1481.

32 Baumann, H., Jahreis, G. P., Sauder, D. N. and Koj, A., J. Biol. Chem. 1984. 259: 7331.

33 Darlington, G. J., Wilson, D. R. and Lachman, L. B., J. Cell Biol. 1986. 103: 787.

34 Amrani, D. L., Mauzy-Melitz, D. and Mosesson, M. W., Biochem. J. 1986. 238: 1443.

35 Woloski, B. M. R. N. J. and Fuller, G. M., Proc. Natl. Acad. Sci. USA 1985. 82: 1443.

$36 \mathrm{Koj}$, A., Gauldie, J., Regoeczi, E., Sauder, D. N. and Sweeney, G. D., Biochem. J. 1984. 224: 505.

37 Perlmutter, D. H., Dinarello, C. A., Punsal, P. I. and Colten, H. R., J. Clin. Invest. 1986. 78: 1349.
38 Tran-Thi, T.-A., Phillips, J., Falk, K. and Decker, K., Exp. Mol. Pathol. 1985. 42: 89.

39 Gebhardt, R. and Mecke, D., Exp. Cell Res. 1979. 124: 349.

40 Tanaka, K., Sato, M. and Tomita, Y., J. Biochem. 1978. 84: 937.

41 Michalopoulos, G. H. and Pitot, H. C., Exp. Cell Res. 1975. 94: 70.

42 Barnes, D. and Sato, G., Anal. Biochem. 1980. 102: 255.

43 Isom, H. C., Selott, T., Georgoff, I., Woodworth, C. and Mummaw, J., Proc. Natl. Acad. Sci. USA 1985. 85: 3252.

44 King, J. and Laemmli, U., J. Mol. Biol. 1971. 62: 465.

45 Bonner, W. M. and Laskey, R. A., Eur. J. Biochem. 1974. 46: 83.

46 Boyum, A., Scand. J. Clin. Lab. Invest. 1968. 21: 77.

47 Northoff, H., Carter, C. and Oppenheim, J. J., J. Immunol. 1980. 125: 125 .

48 Newton, R. C., Immunology 1985. 56: 441.

49 Haq, A. U., Rinehart, J. J. and Maca, R. D., J. Leukocyte Biol. 1985.38: 735 .

50 Northoff, H., Andus, T., Tran-Thi, T.-A., Bauer, J., Decker, K., Kubanek, B. and Heinrich, P. C., Eur. J. Immunol. 1987. 17: 707.

51 Tracey, K. J., Beutler, B., Lowry, S. F., Merrywheather, J., Wolpe, S., Milsark, I. W., Hariri, R. J., Fahey, T. J., III, Zentella, A., Albert, J. D., Shires, G. T. and Cerami, A., Science 1986. 234: 470.

52 Smith, R. A., Kirstein, M., Fiers, W. and Baglioni, C., J. Biol. Chem. 1986. 261: 14871.

53 Ramadori, G., Sipe, J. D., Dinarello, C. A., Mizel, S. B. and Colten, H.R., J. Exp. Med. 1985. 162: 930.

54 Karin, M., Imbra, R. J., Heguy, A. and Wong, G., Mol. Cell. Biol. 1985. 5: 2866.

Note added in proof: After submission of this manuscript Koj, A. et al. (Biochem. Int. 1987. 14: 553) also excluded TNF $\alpha$ as a major acute phase mediator in rat hepatocytes.

Received July 13, 1987. 